\title{
Government of Singapore Investment Corporation (GIC): Insurer of last resort and bulwark of nation-state legitimacy
}

\author{
Gordon L Clark and Ashby Monk
}

Centre for Employment, Work and Finance, School of Geography and the Environment, University of Oxford, South Parks Rd., Oxford OX1 3QY, UK

\begin{abstract}
The global financial crisis has shattered many illusions, one of which being that sovereign wealth funds (SWFs) are properly treated as arms-length investment institutions subject only to global standards of good governance. In fact, in a number of East Asian countries SWFs have acted as 'insurers of last resort' for their nation-states underwriting financial stability and social welfare. In this paper, we explain how and why this came to pass, arguing that this role serves to sustain the legitimacy of the nation-state as well as justify the separation of SWF assets from the public interest in current consumption and spending. Focusing upon the Government of Singapore Investment Corporation (GIC), we suggest that the prospect of recurrent financial crises was an important prompt for its establishment in 1981, reinforced by the experience of many East Asian countries in the 1997 Asian financial crisis. The formal constitution of the GIC, the mechanisms by which its reserves are returned to the government in crisis, and the role of different sections of the political elite in managing those assets are explained. Referencing the principles of best-practice fund governance and the Santiago Principles underwriting the legitimacy of SWFs, we also consider the governance of the GIC, especially as regards its investment processes. Implications are drawn for the experience of Western countries, particularly the UK and the USA, wherein the failure of their banking systems has put untold pressures on current and future living standards.
\end{abstract}

Contact.gordon.clark@ouce.ox.ac.uk

Keywords. East Asia, sovereign wealth funds, financial crisis, nation-state legitimacy

JEL Codes. F33, F59, G23

Acknowledgements. This paper was made possible by the support of the Leverhulme Trust for the Oxford project on sovereign wealth funds. It draws inspiration from related research on the governance of financial institutions and especially pension funds in the context of the global financial crisis in collaboration with Roger Urwin from Watson Wyatt Worldwide (London). As well, the firstnamed author would like to acknowledge the opportunities afforded by Institutional Investor magazine and Dow Jones to speak at conferences on the topic of SWF governance and legitimacy. We would like to record our appreciation for Olga Thönissen's close reading of a previous draft and to the referees for helpful comments. None of the above should be held responsible for any errors or omissions. 


\section{Introduction}

As the assets of sovereign wealth funds (SWFs) grew over the years leading up to the global financial crisis, commentators in the West raised doubts about the intended objectives of these funds. For some, the rapid accumulation of financial assets in a relatively small number of foreign, state-run institutions threatened the power and prerogatives of domestic institutional investors (representing the 'fifth' stage of capitalism; see Clark and Hebb 2004). If nonetheless largely compliant, being enmeshed in the reciprocal interests of complaisant boards of directors (Bogle 2005), 'domestic' institutional investors saw the incursion of 'outside' SWFs into Western capital markets as a threat to their hegemony. ${ }^{1}$ When combined with political fears about SWFs becoming owners of so-called 'strategic' national infrastructure assets like airports, ports, and telecommunications, the legitimacy of SWFs became an important issue for sponsors and for nation-states concerned about the influence of SWFs in domestic and international capital markets (Monk 2009).

The on-set of the global financial crisis saw a rapprochement between SWFs and Western capital markets. ${ }^{2}$ Desperate for market liquidity and for fresh injections of cash in struggling banks and insurance companies, a number of SWFs took significant positions in these firms only to see their stakes massively discounted by the effective failure of the UK and US banking systems. As SWFs lost confidence in the performance and regulation of Western capital markets, their inflows of cash turned to a trickle when international trade stalled and commodity prices declined. It became clear that SWFs were unlikely (and unable) to rescue Western markets; indeed, it became apparent that their assets would be conserved in the interests of their sovereign sponsors-some SWFs appear to have become 'sovereign welfare funds'.

This paper looks at the retreat of SWFs from Western capital markets, arguing that, in a number of cases, they were brought home to act as 'insurers of last resort'. If surprising to a number of Western commentators, it is noted that this role derives from an implicit or explicit commitment of a number of East Asian governments to underwrite national welfare given their experience of global financial markets over the 1990s. Aizenman and Lee $(2008,593-4)$ refer to this policy as a form of foreign reserve "hoarding" wherein "precaution against financial fragility" has been amplified by mercantilist competition between nation-states. This stands in contrast to the recent experience of Western countries, especially the UK and the US, where the lack of domestic savings, and institutions holding assets outside of government budgetary processes, has meant that the public assumption of private debt (due to the global financial crisis) is to be paid for out of the current and future earnings of taxpayers. This is, perhaps, preferable to expropriating or discounting pension assets and benefits (see, respectively, the recent experience of Argentina and Ireland).

\footnotetext{
1\% Lord Myners, an appointed minister in the UK Labour government and a recognised expert in UK corporate governance and institutional investment, argues that a lesson of the global financial crisis is that institutional investors too often ignored their responsibilities and acted like "absentee landlords" where they should have been "engaged" in promoting shareholder value by holding corporate boards of directors accountable: see http://www.hm-treasury.gov.uk/speech_fsst_210409.htm for more details. See also Hebb (2008) on "shareholder engagement”.
}

${ }^{2}$ The Santiago Principles can be read as a reaction to Western anxieties about the objectives of SWFs. These Principles can also be read as an exercise in assuring the political legitimacy of SWF institutions.

Clark and Monk Singapore SWF Version 6 (revised) 
As a member of the International Working Group on SWFs, which developed the Santiago Principles, Singapore's commitment to the Principles has helped to underwrite the international legitimacy of their SWFs. Against those Principles, the GIC has demonstrated a commitment to improving its disclosure and transparency. Indeed, 2008 saw the release of its first ever report describing how the fund is managed and governed. ${ }^{3}$ While this is encouraging, we are more interested in the Singapore government's own legitimacy in the context of the structure and performance of global financial markets.

Barro (2006) demonstrated that the probability of global financial crisis is higher than often assumed. It has also been observed that East Asian economies are more vulnerable than most developing economies to financial volatility because of their long-term export development strategies. As such, we suggest that there is an important role for SWFs as insurers of last resort in underwriting domestic economic growth and consumption. Following the suggestion made by Aizenman and Marion (2004) amongst others, development strategy and market exposure may give rise to problems of political instability if not anticipated by a 'sinking-fund' of some kind.

We suggest that state legitimacy depends upon the extent to which government meets the fundamental interests of its citizens, and the extent to which it can claim a sphere of autonomy in relation to other nation-states and multilateral institutions. The first 'condition' reflects conventional expectations as regards the proper relationship between the state and its citizens. We suggest that the second factor is crucial in understanding the importance of the GIC. As a small country, dependent upon the effective functioning of the global economy for its long-term welfare, Singaporelike other entrepôts - faces an ever-present threat: failure to be globally competitive or, for that matter, overexposure to a failing global economy, could result in it being held hostage to the policies of multilateral institutions or, far worse, the gradual erosion of national sovereignty. It has been observed, for example, that the International Monetary Fund (IMF) claimed considerable influence over policymaking in a number of larger Asian economies in the aftermath of the 1997 Asian financial crisis (Higgott 1998). As is shown below, this incursion and the fear of future incursions into states' sovereignty is what underpins reserve accumulation and the dissemination of SWFs around Asia.

In the next section, we introduce our notion of institutional legitimacy distinguishing between two somewhat different approaches-the normative and the realist or instrumental. Our approach joins the two notions together, arguing, in the case of Singapore, that the GIC was conceived to sustain state legitimacy in the sense of underwriting autonomy and social welfare (stable and smooth consumption) in a manner consistent with a rule-based process of institutional decision-making. This is followed by a discussion of the circumstances facing the Singapore nation-state, drawing upon the literature on East Asian development and the implications of the financial crises of the 1990s for state autonomy. We argue that the vulnerability of Singapore to financial markets and their near-neighbours 'explains' the significance of the GIC as an investment institution for the future. This discussion is augmented

\footnotetext{
3\% Only social security reserve funds claim higher scores on Truman's (2007) index. There are, however, significant differences between SWFs that underwrite pension and retirement benefits and those that have a larger social purpose (see Monk 2009).
} 
with an analysis of rule-based decision-making, drawing upon recent research on bestpractice fund governance. These arguments are illustrated by recent events and the consequences of the global financial crisis for national solidarity. Implications are drawn for the role and nature of SWFs by virtue of national development policy and economic trajectory.

\section{Legitimacy of Institutions}

For liberal theorists, the legitimacy of an institution can be thought to hinge on two rather different reference points: it could be judged against societal norms including moral and political expectations as to proper roles and responsibilities, or it could be judged against accepted standards of performance focusing upon its organisation and instrumental effectiveness (Coleman 2001).

The first theory of institutional legitimacy is essentially normative in that it refers to what an institution should be in some ideal sense. For those concerned about the legitimacy of the nation-state through the cold war and beyond, this issue was conceived in normative terms because debate about legitimacy was more concerned with ideological commitment than what states did or didn't do. These issues preoccupied liberal theorists as much as neo-marxists, both sides being joined together in debate over state legitimacy in the context of the global struggle for hegemony between capitalism, socialism, and communism (Clark and Dear 1984).

That moral philosophy, social norms, and the state are so entwined with institutional legitimacy reflects the history of modern nations; their relevance for Western democracies are matched by their relevance to Central and Eastern European remnants of the Soviet Union and East Asian countries that mix authoritarianism with paternalism in state capitalism (Reus-Smit 1999). Crucially, the normative foundations of state legitimacy are reflected in political rhetoric, argued by some to deliberately obscure the exercise of state power. Runciman (2008, Ch.6) suggests that one reason writers such as George Orwell are held in such high esteem is because of their ability to hold a mirror to modern society so as to demonstrate the hypocrisy of state power and individual complicity. If a reference point for social analysts seeking to expose gaps between the normative bases of state legitimacy and the exercise of state power, there is a core principle that underpins this approach: the legitimacy of state institutions is bound up in social norms that are, no doubt, country and culture specific.

This theory of legitimacy, however, is open to charges of academic irrelevance and naïveté. The counter-argument goes something to the effect that states are what states do, just as institutions are what institutions do. This realist conception of legitimacy works inside and outside of institutions in that 'legitimacy' is claimed by those that control the effective instruments of power in relation to the interests they serve external to state organisations and the ways in which they serve those interests through their relationships with other related institutions. So, for example, it could be argued that nation-states claim legitimacy both with respect to protecting the domestic and international interests of local elites and with respect to preserving their social and political status. In a way, this is an extreme form of functionalism: it treats social norms as simply tools of popular control, wherein institutions take advantage of shared commitments - whether implicit or explicit in social contracts - to deliver benefits to their clientele under the cover of moral commitment. 
The second theory of legitimacy takes as given the purpose of an institution and asks whether the institution is in some way effective in realising that purpose. This suggests that institutions claim their mandates on the basis of their functional effectiveness; it also suggests that institutions are not permanent but can be made and re-made as the underlying 'purpose' changes and as other, more effective, institutions are built to implement that purpose. So, for example, having accumulated foreign reserves over and above short-term needs, nation-states maintain their autonomy and political stability all the while delivering on their commitment to smooth and stable consumption. However, these countries face the issue of how to properly manage those reserves with respect to national objectives (Truman 2007).

A SWF can serve several purposes: it may be the custodian of those assets; it may be a means of separating assets from short-term public spending; it may be the means of managing the costs of holding reserves; and it may be the mechanism for investing those assets in domestic or international financial markets (as in the case of the Australian Future Fund; see Clark 2009). SWFs are probably not, however, institutions for domestic or international economic development, where needed skills and expertise are related to long-term project management rather than portfolio design, financial arbitrage, or trading.

This is, quite clearly, a functionalist conception of institutional legitimacy. As such, it makes three assumptions. First, it assumes that the underlying 'purpose' of the institution is unproblematic or, if contentious, it is assumed that resolution of any related problems is not found in the realm of functional effectiveness. Either way, the 'purpose' of an institution is set outside of the organisation. SWFs are set up to facilitate nation-state objectives; so the institution's warrant is located elsewhere. Second, the design of an institution for a given purpose is a deliberate act of institutional design, although it may happen in many different ways reflecting specific national traditions. Third, there are (probably) standards of performance that guide the design process and the subsequent evaluation of institutional effectiveness. Indeed, institutional purpose, design, and performance are intimately linked to the over-arching claim of nation-state legitimacy. This is a recipe for institutional legitimacy that makes an explicit connection between ends and means in a utilitarian manner (Coleman 2001, 36-37).

For financial theorists concerned about the functional performance of markets in the context of behavioural anomalies, institutional legitimacy is also a question of efficiency. Merton and Bodie (2005), for example, argue that as markets are prone to aberrant behavioural effects, and because many people now rely upon financial markets for their long-term welfare, institutions can play a significant role in dampening the worst effects of behavioural anomalies. By their account, institutions not only frame behaviour but are conceived within certain cultural, political, and social settings to play crucial roles in promoting economic growth. To the extent that institutions sustain market efficiency and social welfare, their functional effectiveness on these counts are two measures of their legitimacy. Notice, though, institutions can not be 'fixed' in form and functions; as behaviour evolves, as markets change and adapt to new situations, and as new threats to social welfare become apparent, the functional legitimacy of any institution depends upon its capacity to either anticipate or at least respond to new realities (Clark and Urwin 2009; Lo 2005). 
But, of course, it is not so simple. Roe (2002), for example, disputes any idealisation of the design process, arguing that, in most cases, institutional form and functions are not 'governed' by a single coherent 'purpose'. In any event, institutions are rarely, if ever, so transparent about their activities and are rarely systematically held to account to the design 'moment'. Institutions have their own lives, foster distinctive decision ecologies, and are subject to considerable ambiguity over how their functions cohere with abstract ideals (March 1997; Kunreuther and Meszaros 1997). Not surprisingly, in terms of institutional performance, tests of institutional legitimacy have tended to focus upon third-party standards of governance and decision-making. At the limit, institutional legitimacy is based upon 'following the rules' (Zhou 1997).

\section{Financial Crisis and State Autonomy}

Our discussion of institutional legitimacy is based upon a distinction between the purpose of an institution and its functional efficiency. This two-sided conception of institutional legitimacy has a number of virtues, not least of which is the realisation that institutions can be thought to operate simultaneously in separate political spheres governed by rather different claims on their performance. In this section, we consider more closely the issue of 'purpose' before returning in subsequent sections to the institutional performance of SWFs, and especially the GIC. Here, we seek to show that, notwithstanding the merits of these two theories of legitimacy, the development trajectory of Singapore and the geopolitics of the region in relation to near-neighbours and multilateral institutions in the context of global financial crises have been such that the Singapore nation-state claims two related 'purposes': maintenance of the nation-state's autonomy and the long-term stabilization of domestic welfare, which we conceive as smooth and reliable consumption over time. The GIC is an institution designed to follow through on these commitments.

Emerging market financial crises typically occur when large-scale capital inflows suddenly reverse and become outflows. In the 1997 Asian financial crisis, Indonesia, Korea, Malaysia, the Philippines, and Thailand saw 1996 net capital inflows of \$93 billion switch to a 1997 net capital outflow of $\$ 12.1$ billion. At the time, short-term foreign exchange liabilities had either grown larger or roughly equal to foreign exchange assets, leaving them extremely vulnerable to capital withdrawals of any kind (Radelet and Sachs 1999). When the sudden and unexpected shift in capital flows took place, it provoked economic contractions throughout the region. ${ }^{4}$ Even countries with sound economic fundamentals such as Taiwan, Hong Kong and Singapore, saw their economies contract considerably due to contagion (see Chart 1). As a result, the Asian crisis was a catalyzing event for many emerging market countries: development states recognized the importance of accumulating and holding international reserves. Going forward, developmental nation-states saw that "hoarding" international reserves was an essential precautionary practice if they were to avoid becoming ensnarled with the IMF and all that implied for their autonomy.

The main objective of the IMF (Article 1) is "to give confidence to members by making the general resources of the Fund temporarily available to them under adequate safeguards, thus providing them with opportunity to correct maladjustments

\footnotetext{
\%. Interestingly, Japanese commercial banks may have initially triggered the crisis. It appears that these institutions had withdrawn 23 billion USD from the Asean-5 by mid-1998 (King 2001).
} 
in their balance of payments without resorting to measures destructive of national or international prosperity." In the Asian crisis, the IMF's response was in two phases. First, between August and December 1997 it offered three urgency lending agreements to Thailand, Indonesia, and Korea. This involved \$17 billion for Thailand, \$35 billion for Indonesia, and \$57 billion for Korea (the actual disbursements were much lower). According to Radelet and Sachs (1999), the first phase of the IMF bailout largely failed to stabilize currency markets and was followed by a second programme based on different principles. In the second phase of the bailout, Radelet, et al. (1998, 60) noted "[s]ome principles, though, remain unchanged, in particular, the targeting of exchange rate stability through high interest rates and restrictive domestic credit policies; and the implementation of a wide range of structural measures in finance, trade, and corporate governance.” In short, in both phases the IMF sought structural changes to the domestic economic policies of these countries.

If the IMF is 'lender of last resort', its support comes with 'strings attached'-when it provides resources to a member country, the funding arrangements specify the conditions underpinning support. Known as IMF 'conditionality', this may include specifying policies that the member country will need to carry out before the arrangement takes place or policies that must be implemented before follow-on disbursements of IMF resources are made. The legal justification for conditionality is found in Article 5 of the IMF Articles of Agreement, which requires adequate safeguards that provide plausible assurances that the money will be paid back. Embedded in conditionality, however, is an assumption that the cause of a crisis is endogenous to the member country (or countries) that seeks financial assistance. Reforming a country's economic policies was thus seen as necessary in order to place the country (and the global economy) on a sounder economic footing that would allow it to 'weather' the current storm and be more resilient in the face of likely future global financial volatility. Systemic global crisis had not been faced until the on-set of the current crisis.

In effect, the IMF has used its leverage to effect changes in countries' internal policies and institutions. This meant, in some cases, that countries seeking IMF assistance were required to adopt policies or to undertake certain reforms championed by the IMF that they would not otherwise adopt. Mussa and Savastano (1999, 84), two IMF employees, conceptualised conditionality as a mechanism for achieving sound economic policies in political environments that might not be able (or willing) to implement such reforms: "[n]ational authorities may modify policies to comply with IMF conditionality when it would be difficult to find domestic political census in the absence of external pressure...the IMF and its conditionality become a scapegoat on both sides of the bargain. That such a scapegoat can be useful in securing necessary or desirable, but unpopular, policy adjustments is clear." The IMF recognised that it has sought to impose its will on sovereign states: intrusion into domestic politics was deemed permissible so as to facilitate 'good governance'. With respect to the Asian crisis, "the IMF's principle strategy for the three countries hardest hit...was to overhaul their financial systems" (Radelet et al. 1998, 1).

Conditionality is a controversial aspect of the IMF mandate (Buira 2003), wherein relying upon the IMF is seen to involve "a loss of national sovereignty over policy" (Bird and Mandilaras 2005, 88). In this vein, Feldstein (1998) offered a critique of conditionality. First, he questioned whether an international agency such as the IMF 
should impose any policies of a domestic nature on sovereign countries. Second, he questioned the morality of taking advantage of short-term financial crises in such a manner. Finally, he argued that the legitimate political institutions of the country seeking IMF assistance should determine the nation's economic structure and the makeup of its institutions: "[i]mposing detailed economic prescriptions on the legitimate governments would remain questionable even if economists were unanimous about the best way to reform the countries' economic policies" (Feldstein 1998, 28).

The Asian crisis taught a valuable lesson to many countries' policy-makers: that avoiding the IMF-sponsored insurance regime and the associated conditionality programmes were in their countries' interest (Stone 2008). If they saw their legitimacy in terms of the agreed purpose(s) of the nation-state and the institutional capacity to realise those objectives, ensuring nation-state autonomy would be a crucial means of doing so.

\section{Precautionary Strategy in an Uncertain World}

The Asian crisis led to "profound changes in the demand for international reserves, increasing over time the hoarding by affected countries" (Aizenman and Lee 2007, 192). Hoarding was driven by a recognition among Asian countries that selfinsurance was preferable to IMF conditionality and the associated loss of sovereignty. Nevertheless, holding reserves is not without its own costs. Indeed, taken as a whole, Rodrick (2006) estimated that reserve accumulation costs emerging market countries $1 \%$ of GDP annually. At this elevated price, countries began looking for innovative ways to keep these costs down. This is the origin of 'reserve investment corporations'; a type of SWF. Countries hoped costs could be minimized by investing a portion of their reserves in higher yielding asset classes in international markets. Paradoxically, while many SWFs were conceived (in part) to be a part of emerging markets' selfinsurance policies, underwriting national sovereignty in times of financial crisis, the opportunity costs of such strategy has had to be realised through investment in global financial markets. ${ }^{5}$

In this respect, the case of Singapore illustrates the utility of hoarding reserves, as the Asian crisis left the island nation relatively unscathed compared to its neighbours (see Chart 2). In fact, Singapore actually participated as a creditor in the IMF-led programmes, promising loans of $\$ 1$ billion to Thailand and $\$ 5$ billion to Indonesia. That is not to say that Singapore did not feel any of the ramifications from the crisis; the Singapore dollar depreciated by roughly 15\% relative to the US dollar (between July 1997 and March 1999), and Singapore's economic growth slowed from 8.3\% in 1997 to $-1.3 \%$ in 1998 . However, the economy managed $7.2 \%$ growth in 1999 and $10 \%$ in 2000. In comparison to the other regional economies, this was a remarkable achievement; a performance that reinforced the importance of holding reserves (for Singapore and its neighbours). Indeed, Jin (2000) explicitly cited Singapore's "huge foreign exchange reserves" and "substantial budget surpluses" as being important factors in Singapore's resilience during the crisis (see also Rajan et al. 2002).

\footnotetext{
5 . There are other benefits to self-insurance as well: relying on domestic institutions affords countries more flexibility, as they are seen to be more nimble in times of crisis-when speed of policy implementation is crucial—-than the IMF (see Mishkin 1999).
} 
The origins of Singapore's precautionary policies are to be found in the actions and intentions of its founding Prime Minister. As the Chairman of the GIC and past Prime Minister, Lee Kuan Yew (2006), in an address commemorating the $25^{\text {th }}$ anniversary of the GIC, noted that it was established in 1981 "in a turbulent international financial market." He commented on the significance, at that time, of oil price inflation, the possibilities of Latin American sovereign default, banking insolvencies, and the problems then facing the US economy. In that context, he stated "my cardinal objective for GIC was not to maximise returns but to protect the value of our savings and earn a fair return on capital." Close to the peak in the sub-prime fuelled global financial bubble in asset prices, he reported that the GIC managed over US\$100 billion in assets and had produced an average annual rate of return on foreign reserves of 9.5 per cent (in US dollar terms) over the period 1981-2006. It is now one of the world's largest SWFs, and can claim to be one of the best managed, even if its governance score placed it below average for non-pension SWFs (Truman 2008).

Being an export-led economy, Singapore imports virtually all its raw materials and energy. As such, it relies upon the Middle East for oil imports and Malaysia and Indonesia for natural gas imports representing in total 10 per cent of annual export earnings (2008). Singapore's reliance upon its near-neighbours for natural resources including water is one element in complex political relationships with the world's largest Muslim democracy (to the south) and its former Federation partner (to the north). A small country of 4.6 million people, Singapore has a GDP per capita that matches Western European countries, whereas Malaysia (25.7 million) and Indonesia (240 million) reported in 2008 GDP per capita of, respectively, US\$15K and US\$3.9K (2008). Recognising Singapore’s vulnerability, in their 2007/08 annual report the GIC noted that "with no natural resources to keep the country going in times of crisis or severe economic dislocation, these (foreign) reserves are a nest egg, a safeguard against unforeseen circumstances, and the means to mitigate shocks that might hit Singapore's small and open economy". ${ }^{6}$

Conceptualizing the GIC as a strategic institution for managing the possible adverse consequences of living in an uncertain world has been an effective way of legitimating the GIC and separating a portion of foreign earnings on trade and exchange from current revenue and expenditure. It could be argued that this strategy is similar to that of the conservative Liberal government in legitimating the establishment of the Australian Future Fund in the mid 2000s (Clark 2009). In effect, both governments have been able to separate a portion of the earnings from trade from the domestic political pressures to spend the money for short-term political advantage. But notice two distinctive aspects of the Singapore case: Singapore's geopolitical vulnerability in having no natural resources, and the more limited role of parliamentary democracy in the life of Singapore government and politics. In the first instance, there is an unstated but apparent threat from near-neighbours should Singapore not be financially resilient. If this seems rather abstract and perhaps distant given the mutual benefits in promoting trade and development involving the

\footnotetext{
6. The current Singapore Prime Minister also noted in parliamentary debate over the FY2009 budget that "the reserves are something which we have built up for a rainy day because we are highly dependent on imports. We have no natural resources.”
} 
immediate and adjacent regions of northern Indonesia and southern Malaysia, history can be invoked to tell a more realist story of geopolitics.

In the second instance, it is arguable that secure, long-term prosperity is the 'promised' benefit of a limited form of popular politics. Were the Singapore government forced to rely upon the IMF in the case of financial crisis, it is arguable that it would be vulnerable twice-over: to external geopolitical forces and to internal political dissent. Here, it is also arguable that the unstated social contract binding the government to its citizens is one where the state is presumed to protect the interests of its citizens from external threats in exchange for the compliance of the populationby this reading of the 'deal' struck when the GIC was established, notwithstanding the apparent constraints of current consumption, foreign earnings have served to sustain the bargain made by the public with its state.

Remarkably, the recent global financial crisis has served to further reinforce the utility of Singapore's SWFs to the government, as it tapped its reserves for the first time so as to stave off economic dislocation. As such, we might agree with Reus-Smit (1999, 32-33) where he argued that the moral purpose of the state is realised through the agreement of the public about what counts as its substantive goals. In Singapore's case, smooth consumption, autonomy and political stability are important components of that larger purpose. ${ }^{7}$ In a precarious world, SWFs are important economic tools to ensure these political and social objectives are met.

\section{Governmentality and Functional Legitimacy}

Apart from its location at the interstices of global trade, Singapore's comparative advantage is its human capital. This has three dimensions, the most obvious being its highly educated workforce augmented by a strategic immigration policy designed to fill identified skill-shortages (Vietor 2007). A second element in Singapore's human capital strategy is to be found in attempts to foster skill-based industrial development focused upon industries and sectors consistent with Singapore's entrepôt status in the global system of trade and exchange (linking Western multinational companies with the burgeoning consumer markets of South-East and North-East Asia).

The third element, and crucial for our analysis of Singapore's formation and management of the GIC, has been its governmentality: that is, the Singapore government's capacity to conceive development and investment strategies, ensure their effective implementation, and realise the benefits of those strategies over the long-term rather than spending benefits as 'windfalls' so as to buy political commitment by sectional interests (see Clark 2009 on Australia's Future Fund). While politically expedient, this strategy necessitates a certain threshold of institutional efficiency in order to achieve domestic legitimacy (even if the SWFs's purpose is likely the most compelling criteria in Singapore). As such, we explore here the structure and management of the GIC in the light of whether it conforms to bestpractice models of investment management, as defined both by the Santiago Principles and the principles for investment management by Clark and Urwin (2008).

\footnotetext{
${ }^{7}$ We could also analyse the contribution of Singapore's SWFs to the growth of the city-state as a financial centre in South-east Asia. In this paper, however, that particular part of the story is less significant than the issue of macroeconomic stability. See Lee Kuan Yew's (2000) account of the creation of the SWFs and their importance in underwriting the Singapore financial services industry.
}

Clark and Monk Singapore SWF Version 6 (revised) 
The form of an institution is important: witness the significance of this issue for the Generally Accepted Principles and Practices (GAPP, or the Santiago Principles), and specifically GAPP 1, which states that "the legal framework for the SWF should be sound and support its effective operation and the achievement of its stated objective(s)." Formally, the GIC has many of the best features of Anglo-American financial institutions including being managed as a separate (but wholly owned) company of the Singapore Government with a board of directors, and investment, risk, and remuneration sub-committees. As in UK corporate law, the board is comprised of executive and non-executive members, in this case split between 3 government members, 4 independents, and 6 GIC executives. The functions of Chairman and Chief Executive Officer are separate although there are, in fact, nominally 3 'chairs' (the founding Prime Minister, a Deputy, and the GIC Executive Director). The investment sub-committee is chaired by the Deputy Chairman and executive director of the GIC and combines 3 government ministers with 3 external advisors, 2 independent directors and 1 executive director. Remarkably, the risk sub-committee is chaired by a government minister and is comprised of 2 independent directors and 1 external advisor. ${ }^{8}$

The formal division of powers between different types of directors and advisors could be thought to combine the legitimate interests of the government as the sole shareholder with senior managers and knowledgeable independent directors and external experts. However, it is arguable whether the independent directors are as 'independent' as expected in Anglo-American corporations-both the CEO of Singapore Airlines and the CEO of the Singapore Exchange have close relationships with government given that it holds a majority of shares in both companies. Questions could also be raised about the actual influence of independent expert advisors given that they do not actually sit on the main board of the institution. Even so, it should be acknowledged that Anglo-American companies may be faulted on a number of counts: some companies have combined the roles of Chair and CEO, nonexecutive board members have not been as independent as desired, the interests of shareholders have been ignored, and external advice has been discounted by entrenched interests (see Sants 2009 on recent UK experience).

Despite the domestic backlash against the GIC's investment performance in the crisis, it actually matches up well to international standards of practice. Clark and Urwin's (2008) principles of best-practice pension fund investment are especially relevant, in part because a number of the leading SWFs are, in fact, sovereign pension funds (see Truman 2008). These 12 principles are organised into three separate groups: in order, institutional coherence (principles 1-3) which include reference to mission clarity and the institutional allocation of tasks; the management of human capital (principles 4-6) which include reference to leadership, the division of powers and responsibilities, and compensation practices; and the process of investment (principles 7-12) which include reference to operational goals, the delegation of tasks, risk budgeting and the nature

\footnotetext{
$8 \%$ The formal separation of risk assessment from investment management is characteristic of innovative financial institutions concerned to ensure that investment is a disciplined process with a risk budget that reflects the long-term objectives of the institution (Clark and Urwin 2009). Not only is the GIC risk sub-committee small, no executive director is a member of that committee. Its influence hinges, though, on the reputation of the single external expert.
} 
and use of available resources. Based on these benchmarks, the GIC appears effective at its job.

These principles of best-practice take as given the goals and objectives of funds and seek to evaluate operational form and functions. As such, a more contentious issue, and one that animated the development of the Santiago Principles, concerns the operational goals of SWFs: principle 19 states that "SWF's investment decisions should aim to maximize risk-adjusted financial returns in a manner consistent with its investment policy, and based on economic and financial grounds." This is consistent with Clark and Urwin's argument in favour of clarity of mission even if best-practice is not necessarily about maximising returns - there being considerable differences between institutions and jurisdictions over the relevance of this particular goal. For example, it is arguable that asset-liability matching is at least as important if not more important than maximising returns within certain financial institutions, such as pension funds (see Baer et al. 2006). In the Singapore case, of course, this objective is too simple: it fails to recognise the long-term, precautionary purpose of the GIC and the stated goal of balancing returns against security of assets. ${ }^{9}$

A variety of rationales have been offered justifying the 24 Santiago Principles. In the report of the International Working Group of Sovereign Wealth Funds (involving 23 countries including Australia, China, and Singapore and another 5 observer countries and institutions) reference was made to the stability of the global financial system, maintenance of an "open and stable (global) investment climate", and the value of "a sound governance structure that separates the functions of the owner, governance body(ies), and management (that) facilitates operational independence." As noted above, the research by Clark and Urwin (2008) on best-practice investment management clearly supports the importance of effective governance. Truman's (2008) work on scoring sovereign wealth fund best-practice also supports effective governance. In his case, though, there is also considerable emphasis on accountability and disclosure justified by reference to global financial stability and the International Monetary Fund's (1998, v) statement, in the aftermath of the Asian financial crisis, to the effect that transparency and accountability "might have helped to prevent the build-up of financial and economic imbalances, induced a prompter adjustment in policies, and limited contagion.”

To the extent that the Santiago Principles are consistent with Clark and Urwin's principles of best-practice investment management, they cohere with claims of legitimacy based upon functional effectiveness. Even so, the Finance Minister of Singapore in supporting the Santiago Principles noted that "key" components of the Principles were public disclosure and accountability and that, subject to Singapore's long-term interests, the GIC (and Temasek Holdings, the country's other SWF) would "adhere to these principles and practices". The Singapore Government's support of the Santiago Principles suggested that, for the world at large, the legitimacy of SWFs

\footnotetext{
9 . Throughout the commentary offered by the International Working Group on the rationale underpinning the Santiago Principles, the focus was on the interests of "home countries" and "recipient countries" and the prospect for establishing "trust" between the two (Monk 2009). Implied is a fear that SWF investments may precipitate protectionist sentiment if the objectives of SWF investors are either obscure or are counter to the conventional ethos of maximising returns that dominates the AngloAmerican investment management industry (see Litterman 2003).
} 
hinges on the underlying purpose of those funds and that functional performance is a secondary test of legitimacy.

\section{Constitutional Integrity of the GIC}

The above principles and practices represent mechanisms through which the GIC has sought to achieve international legitimacy and, to some extent, domestic legitimacy through functional efficiency. ${ }^{10}$ Nevertheless, domestic legitimacy is based on more than just performance. As such, the Government of Singapore has taken its own steps to ensure that the GIC's purpose, mandate, and accountability structure, which are crucial components of institutional legitimacy, are enshrined in the country's Constitution.

Reserves are accumulated in the key Statutory Boards and Government Companies (SBGCs) listed under the Fifth Schedule (such as the GIC) of the Singapore Constitution. There are various checks and balances by the Singaporean Constitution that safeguard these reserves from misuse. In fact, Singapore's Constitution actually ties the hands of all future governments with respect to using reserves, allowing them to draw down on only the reserves accumulated during the term of office of the government. In this way, Singapore is stricter with its reserves than Australia, which holds to the principle that the current Parliament cannot tie the hands of future Parliaments (Clark 2009).

'Past reserves' in Singapore may not be drawn down without fulfilling a specifically defined protocol based largely on a "two-key system." The Government and the President each hold keys that must be "turned simultaneously" to unlock the reserves. In short, past reserves can only be accessed if both the Government and the President agree that the current conditions warrant such a decision and the programmes being considered meet certain specifications and do not violate prior commitments. This safeguard relies on the political independence of the President from the Government, which is why the President is directly elected and forbidden from being a politician, member of a political party or holding any government jobs at the time of his election or during his tenure as President (see Section 19(2)f,g).

These constitutional arrangements were designed to ensure that the President remains focused on his primary objective: protecting the integrity of Singapore's strategic assets, as described in the Constitution. Indeed, according to Section 17 and Section 21 of the Constitution, the President of Singapore shall exercise certain powers over government run companies and assets. The President receives regular and detailed accounts of the GIC. Moreover, he has the right to ask for additional information about the GIC to fulfil his duty of protecting Singaporean assets and reserves. The

\footnotetext{
${ }^{10}$ As noted above, the Santiago Principles appear to emphasize the public accountability and disclosure of SWFs' activities with respect to the interests of external stakeholders'. Of the 24 principles, 8 would appear to be about accountability and 8 would appear to be about disclosure albeit reasonable to suggest that the 8 principles dealing with governance partially overlap with accountability and disclosure as in the case of principle 21, which deals with the exercise of SWFs ownership rights in relation to investment policy and public disclosure of its policies. It could be argued, as also implied above, that these principles seek to assuage international concern about the goals and objectives of SWFs. Nonetheless, there remains a possibility that the principles may well have been conceived to reach domestic stakeholders including the public at large. In doing so, these principles may be enlisted to insert liberal values of state accountability into political systems that are anything other than 'democratic'.
} 
Minister for Finance, Accountant-General and Auditor-General are also required to update the President of any proposed transaction which could draw on past reserves. The GIC's annual budgets and appointment of board members/company directors also require the approval of the President.

Specifically, the President may withhold his assent to certain Bills, budgets and appointments to statutory boards and Government companies (22A and 22C). Sections 22B and 22D of the Constitution, in effect, give the President the right to refuse any budget or supplementary budget of any statutory board or Government company if, in his opinion, the budget is likely to draw on reserves which were not accumulated during the current term of office of the Government. The exception to this occurs if the Government seeks the President's approval for a budget or policy that specifically seeks to draw on past reserves (see 22(B)7 and 22(D)7). In this case, the President still acts in his capacity as guardian of these reserves, but he instead evaluates the merits of the Government's case. In this instance, if the President agrees to using the past reserves, he must publish why he approves tapping past reserves in the Government Gazette. Since the Constitution enables the Government but not the President to propose the draw-down of foreign reserves, this provides a de facto constraint on public claims on GIC assets while the President's powers of review provide an explicit constraint on the Government's revenue and spending intentions.

This begs the question: when can the government tap reserves? This is where things get a bit murky. The Government recently sought to clarify what, in its terms at least, would NOT qualify as legitimate draw-downs on foreign reserve assets. In the context of the present global financial crisis, Senior Minister Goh Chok Tong indicated there were three situations or claims for support where GIC reserves should not be sourced. ${ }^{11}$ First, the Minister indicated that reserves could not be drawn down to support social assistance programmes. In the context of the current stimulus, however, the reserves did indeed go to some social welfare programs, such as workfare subsidies, jobs credits and direct assistance to families. Second, the reserves should not be drawn down for permanent government programmes, as these should be funded out of current revenues and reserves; this appears to have held up during the current stimulus, as the support for small and medium enterprises was not permanent. Third, reserves can not be used in any situation that is not a "dire circumstance," requiring reserves to ward-off catastrophe or prevent irreparable damage to the economy. ${ }^{12}$ This seems to be the primary consideration for using past reserves.

So, while the generic basis for tapping reserves is enshrined in the constitution, the above illustrates that some of the protocols remain poorly defined. For example, the constitutional process through which the President decides whether to 'turn his key' is unclear. According to the current President, "the Constitution does not prescribe the process for dealing with a request for using past reserves beyond the need for me to consult with the Council of Presidential Advisers and to publish my view that there is a draw on past reserves when I so approve a draw." ${ }^{13}$ In the current crisis, the

\footnotetext{
11\%.http://app.mof.gov.sg/data/FY2009_Budget_Debate_Round_Up_Speech.pdf

12/. http://www.news.gov.sg/public/sgpc/en/media_releases/agencies/csg/speech/S-20090201-1.html
} 
decision to unlock past reserves took just 11 days, which raised concern within Singapore's government. Opposition MP Low Thia Khiang noted "past reserves are supposed to be protected by a two-key system. The government holds one key, while the President holds the second key. But the speed at which the two-key system can unlock the reserves is too fast for comfort." 14 Further, according to Nominated MP Siew Kum Hong "there has been precious little information about the deliberations of the President or of the Council of Presidential Advisers in giving in-principle approval to use the reserves." In effect, the two-key system rests on the credibility of the Government and of the Elected President and his advisers. Moreover, the integrity of this safeguard relies on the political independence of the President from the Government, which some commentators suggest does not exist (see Tam and Lam, 1997).

Notwithstanding these concerns, the GIC and the reserves it manages have been constitutionally protected from immediate political claims so as to ensure that the country holds onto its autonomy and lives up to its commitment of smoothing consumption. Domestic political legitimacy is thus based on the GIC's role as 'insurer of last resort', conceived in the first instance to protect Singapore's savings in an uncertain financial world, insure its independence from near-neighbours and distant suppliers, and capitalise the benefits of long-term growth in case of "unforeseen circumstances". ${ }^{15}$ The actions of the IMF in countries most affected by the Asian financial crisis of the late 1990s represented for Singapore the kind of threat to its sovereignty that the GIC was established to insure against. Granted, Singapore did not claim the financial support of the IMF or have to agree to the policies of the multilateral institution in order to deal with the crisis. Nonetheless, commentaries in Singapore and in the informed policy commentary at the time suggested that without the existence of the GIC as 'insurer of last resort' the Singapore government could have been forced to accept IMF support thereby compromising the autonomy of Singapore's government in favour of the IMF's neoliberal agenda (see Rajan et al. 2002; Jin 2000).

\section{Implications and Conclusions}

Our analysis of Singapore's GIC was premised upon a two-sided conception of institutional legitimacy: at one level focused upon the 'purpose' of the investment institution, and at another level focused upon the functional arrangement of its management and responsibilities. By our assessment, the purpose of the GIC is plain - to be the nation-state's insurer of last resort in the context of an uncertain world. In part, this assessment is driven by the stated purpose of the GIC as articulated by the founding Prime Minister and the experience of Singapore and its East Asian neighbours through the 1997 Asian financial crisis and the policies and practices of the International Monetary Fund. Being insurer of last resort has meant

\footnotetext{
$13 \%$

http://www.straitstimes.com/STI/STIMEDIA/sp/budget09/concerns_about_economy_go_back to mid 2008.html

14/. http://sgblogs.com/entry/welcome-move-reserves-warn-against-precedence/285315

15\% Reinforcing these points, the current Singapore Prime Minister noted in parliamentary debate over the FY2009 budget that "the reserves are something which we have built up for a rainy day because we are highly dependent on imports. We have no natural resources.”
}

Clark and Monk Singapore SWF Version 6 (revised) 
underwriting the autonomy of the nation-state's government as well as the long-term welfare of its citizens. We argue that these two elements are closely related, reflecting an implicit social contract between the state and its constituents: the state is accorded significant powers in relation to a possible hostile world in exchange for its commitment to the long-term wellbeing of its constituents. Notice, though, that this commitment is an agreed constraint on current consumption; not all Singaporeans would agree with this 'deal'. Indeed, Singapore's SWFs have been the subject of criticism by certain Singaporean constituencies.

In terms of functional efficiency, we assessed the GIC's management and responsibilities against two standards - those proposed by Clark and Urwin (2008) as regards best-practice investment management and those proposed by the Working Group on SWFs as regards the 'accepted' Principles of management. Here, we noted that the GIC's formal allocation of powers and responsibilities between its board and its managers matches, in many respects, the best-practice standards articulated by Clark and Urwin. It is also apparent that the Santiago Principles have been accepted by the Singapore government and the GIC. But it is suggested that the Santiago Principles may be more related to the external legitimacy of SWFs in a world hostile to the emerging power of SWFs than their functional effectiveness. Similarly, given the focus of the Santiago Principles on disclosure and transparency it is possible that embedded in these principles is a conception of the modern state that owes more to Western notions of liberal democracy than the culture and traditions of SWF sponsors.

It is arguable that Singapore's commitment to self-insurance is a reflection of its size, geopolitical setting, and lack of resources in a region of the world that could be hostile to its pretentions to independence and economic prosperity. Being insurer of last resort, the GIC has the financial assets to not only underwrite state autonomy and long-term welfare but also to underwrite the stability of the nation-state's financial system and its banking institutions. When combined with the apparent constraints on domestic consumption affected by the sequestering of foreign earnings, the government has effectively invented a means of managing financial stability and macroeconomic management. In a way, this is an 'unintended' result of Singapore's geopolitical strategy. But it has paid dividends in the current crisis, and reflects a commitment to macroeconomic management and stability that was a motivating force in the formation of Australia's Future Fund (Clark 2009).

By contrast, the recent experience of Western economies and in particular the UK and the USA suggests that the lack of an effective national insurer of last resort has proven to be a real threat to economic prosperity. In these countries, nation-states became by default the insurers of last resort, offering-up their current and future tax revenue as the means of underwriting the stability of their financial systems. It would appear that the prior 'stress-testing' of countries' financial systems (if any) focused upon the resilience of individual banks rather than whole systems, focusing upon the distribution of idiosyncratic risks instead of the robustness of national regulatory systems in the face of systemic risk. As has become apparent, the global scale of the crisis and the overwhelming size of banks deemed too large to fail by their national sponsors are such that leveraging nation-state tax revenue proved to be inadequate in the face of the looming disaster. Furthermore, possible 'solutions' to the crisis canvassed by nation-states facing much higher levels of indebtedness are likely to destabilize macroeconomic conditions over the near-term, producing increasing levels 
of inequality amongst different classes of citizens more or less vulnerable to these conditions.

Obviously, there is more to the global financial crisis than nation-state banking regulation and solvency. Nonetheless, a contrast can be drawn between Singapore's precautions taken to protect national sovereignty and stability in the case of a global or regional financial crisis and the willingness of Anglo-American governments to spend current and future income on consumption as if financial instability could be absorbed within existing national regulatory institutions. It is instructive that two of our SWF case studies-Australia's Future Fund and Singapore's GIC-have seen their respective governments make deliberate choices about the mix between current consumption and future national welfare, managing the political process in each country so as to balance temptation against national sovereignty. Obviously, the balance struck between short-term political opportunism and the long-term common good is contestable-most obvious, perhaps, in Australia but nonetheless embedded in the polity of Singapore. It is intriguing that, in both the UK and the USA over the first decade of the twenty-first century, majority political parties were not able to look beyond short-term interests.

Our case study suggests that no country, however large, can afford not to build institutions that may act as insurers of last resort. As Barro (2006) has noted, financial crises are endemic to the world economy and may be more so as globalization draws into the centre of trade and exchange national failures of financial management. At one level, this may require national policies that balance short-term consumption in favour of long-term saving (as suggested above). But, of course, it is the case that both the UK and the USA (and other Western countries) have had active policies that promote saving-the difference is that these policies have promoted private pension saving through individual and collective contracts. So successful, in fact, have these policies been that these countries' economies have been re-fashioned in the face of the imperatives driving 'pension fund capitalism' (Clark 2000). The issue here is problematic: the extent to which private pension saving institutions, albeit underwritten by generous government tax provisions, should or could be mobilised to underwrite financial stability where governments are unable to do so.

Can these types of financial institutions act as insurers of last resort as the Singapore GIC? If we refer back to an institution's objectives and mandate, the only answer that would preserve legitimacy and maintain the integrity of governance would be 'no'. By answering 'yes' - as Ireland recently did - the government would be expropriating pension savings (future income) to 'save' current welfare. While this may seem appropriate given current circumstances, it contradicts the very foundations of the institution, which draw its domestic legitimacy from the fact that it was set up to resolve future economic problems (e.g. an unfunded pension liability) not today's.

The other alternative is, of course, the notion of an "international lender of last resort" (Fischer 1999). For all its current significance and the recurrent nature of financial crises that have exacted significance welfare costs on the peoples of the globe, there remain considerable hurdles to be over-come in realising its promise. One that is to be learnt from our Singapore case study is that when the benefits and costs of selfinsurance are located close to the polity there may be a better realisation of the need to manage consumption over the short-term and the long-term. Likewise, given the 
opportunity costs of sacrificing current welfare for future welfare in the context of managing an uncertain world, it may be the case that some polities are better able at realising the advantages than others-moral hazard, an ever-present danger is such arrangements-may be, paradoxically, more often found in those countries that seem to dominate the world. 


\section{References}

Aizenman, J. and J. Lee (2004). "International Reserves Holdings with Sovereign Risk and Costly Tax Collection”. Economic Journal 114:497-

Aizenman, J. and J. Lee (2007). "International Reserves: Precautionary Versus Mercantilist Views, Theory and Evidence”. Open Economic Review. 18:191-214.

Aizenman, J. and J. Lee (2008). "Financial versus Monetary Mercantilism: Long-run View of Large International Reserves Hoarding”. The World Economy

Barro, R. (2006). Rare disasters and asset markets in the twentieth century. Quarterly Journal of Economics. 114:823-64

Bird, G. and A. Mandilaras (2005). "Reserve Accumulation in Asia: Lessons for holistic reform of the international monetary system". World Economics. 6(1): 85-99.

Bogle, J. (2005). The Battle for the Soul of Capitalism. New Haven: Yale University Press.

Buira, A. (2003). “An Analysis of IMF Conditionality”. G-24 Discussion Paper Series: No. 22.

Clark, G. L. (2000). Pension Fund Capitalism. Oxford: Oxford University Press.

Clark, G. L. (2009). “Temptation and the Virtues of Long-Term Commitment: The Governance of Sovereign Wealth Fund Investment”. Available at SSRN: http://ssrn.com/abstract=1349123

Clark, G. L. and M. J. Dear. (1984). State Apparatus. London: Allen and Unwin.

Clark, G. L. and T. Hebb. (2004). "Pension Fund Corporate Engagement: the Fifth Stage of Capitalism”. Relations Industrielles/Industrial Relations. 59:142-71.

Clark, G. L. and Urwin, R. (2008). Best-practice Investment Management. Journal of Asset Management. 9(1):2-21.

Clark, G. L. and Urwin, R. (2009). "Innovative Models of Pension Fund Governance in the Context of the Global Financial Crisis”. Pensions: An International Journal (forthcoming).

Coleman, J. L. (2001). The Practice of Principle: In Defence of a Pragmatic Approach to Legal Theory. Oxford: Oxford University Press

Feldstein, M. (1998). “Refocusing the IMF”. Foreign Affairs. March-April, 77(2): 2034.

Feldstein, M. (1999). “A Self-Help Guide for Emerging Markets”. Foreign Affairs. March/April 1999. 
Fischer, S. (1999). “On the Need for an International Lender of Last Resort”. Journal of Economic Perspectives 13:85-104.

Hebb, T. (2008). No Small Change: Pension Funds and Corporate Engagement. Ithaca NY: Cornell University Press.

Higgott, R. (1998). "The Asian Economic Crisis: A Study in the Politics of Resentment”. New Political Economy 3:333-56

Jin, N. K. (2000). "Coping with the Asian Financial Crisis: the Singapore Experience”. Institute of Southeast Asian Studies, Visiting Researchers Series no. 8.

King, M. R. (2001). "Who Triggered the Asian Financial Crisis?" Review of International Political Economy. 8:438-466.

Kunreuther, H. and Meszaros, J. (1997). "Organizational Choice under Ambiguity: Decision Making in the Chemical Industry Following Bhopal”. In Organizational Decision Making edited by Z. Shapira. Cambridge: Cambridge University Press, pp. 61-80.

Litterman, B. et al. (2003). Modern Investment Management: An Equilibrium Approach. Wiley: New York.

Lo, A. (2005). “The Adaptive Markets Hypothesis: Market Efficiency from an Evolutionary Perspective. Journal of Portfolio Management. 30:

March, J. (1997). “Understanding how Decisions Happen in Organizations”. In Organizational Decision Making edited by Z. Shapira. Cambridge: cambriudge University Press, pp. 9-33.

Mendoza, R. U. (2004). "International Reserve-Holding in the Developing World: Self Insurance in a Crisis-Prone Era?” Emerging Markets Review. 5(1): 61-82.

Merton, R. and Bodie, Z. (2005). "The Design of Financial Systems: Towards a Synthesis of Function and Structure. Journal of Investment Management. 3:1-23

Mishkin, F. S. (1999). "Lessons from the Asian crisis". Journal of International Money and Finance. 18:709-23.

Monk, A. H. B. (2009). "Recasting the Sovereign Wealth Fund Debate: Trust, Legitimacy and Governance”. New Political Economy. Forthcoming.

Mussa, M. and M. Savastano (1999). “The IMF Approach to Economic Stabilization”. NBER Macroeconomics Annual, 14:79-122.

Radelet, S., J. D. Sachs, R. N. Cooper, and B. P. Bosworth (1998). "The East Asian Financial Crisis: Diagnosis, Remedies, Prospects”. Brookings Papers on Economic Activity. 1: pp. 1-90. 
Radelet, S. and J. Sachs (1999). "What Have We Learned, so Far, from the Asian Financial Crisis?”

Rajan, R., R. Sen and R. Y. Siregar (2002). "Hong Kong, Singapore and the East Asian Crisis: How Important were Trade Spillovers.” Centre for International Economic Studies Discussion Paper No. 0042.

Reus-Smit, C. (1999). The Moral Purpose of the State. Princeton: Princeton University Press.

Rodrik, D. (2006). “The Social Cost of Foreign Exchange Reserves”. NBER Working Paper 11952.

Roe, M. J. (2002). “Political Foundations for Separating Ownership from Control. In Corporate Governance Regimes: Convergence and Diversity edited by J. A. McCahery, P. Moerland, T. Raaijmakers, and L. Renneboog. Oxford: Oxford University Press, pp. 113-46.

Runciman, D. (2008). Political Hypocrisy. Princeton: Princeton University Press.

Sants, H. (2009). "Delivering Intensive Supervision and Credible Deterrence". London: Financial Services Authority. Available at www.fsa.gov.uk/

Stone, R. W. (2008). “The Scope of IMF Conditionality”. International Organization. 62: 589-620.

Tan, K. and Lam P. E. (1997). Managing Political Change in Singapore. Eds. London: Routledge.

Truman, E. (2007). "Sovereign Wealth Funds: The Need for Greater Transparency and Accountability”. Policy Brief P807-6. Washington DC: Peterson Institute.

Truman, E. (2008). “A Blueprint for Sovereign Wealth Fund Best Practices”. Policy Brief P808-3. Washington DC: Peterson Institute.

Vietor, R. H. K. (2007). How Countries Compete: Strategy, Structure, and Government in the Global Economy. Boston: Harvard Business School Press.

Yap, S., Lui, R., and Kau, L. W. (2009). Men in White: The Untold Story of Singapore's Ruling Party. Singapore: Marshall Cavendish.

Yew, L. K. (2000). From Third World to First World: The Singapore Story 19652000. Singapore: Marshall Cavendish.

Zhou, X. (1997). “Organizational Decision Making as Following a Rule”. In Organizational Decision Making edited by Z. Shapira. Cambridge: Cambridge University Press, pp. 257-84. 


\section{APPENDIX:}

\section{CHART 1}

\begin{tabular}{|lrrrrrr|}
\hline Country & \multicolumn{7}{c|}{ Gross domestic } & product, \% change & & \\
\hline Hong Kong & $\mathbf{1 9 9 5}$ & $\mathbf{1 9 9 6}$ & $\mathbf{1 9 9 7}$ & $\mathbf{1 9 9 8}$ & $\mathbf{1 9 9 9}$ & $\mathbf{2 0 0 0}$ \\
Indonesia & 2.3 & 4.2 & 5.1 & -6.0 & 2.6 & 8.0 \\
Korea & 8.2 & 7.8 & 4.7 & -13.1 & 0.8 & 5.4 \\
Malaysia & 9.2 & 7.0 & 4.7 & -6.9 & 9.5 & 8.5 \\
Philippines & 9.8 & 10.0 & 7.3 & -7.4 & 6.1 & 8.7 \\
Singapore & 4.7 & 5.8 & 5.2 & -0.6 & 3.4 & 6.0 \\
Taiwan & 8.2 & 7.8 & 8.3 & -1.4 & 7.2 & 10.1 \\
Thailand & 6.5 & 6.3 & 6.6 & 4.5 & 5.7 & 5.8 \\
\hline
\end{tabular}

Source: IMF, World Economic Outlook Database, October 2008

Notes: Values are based upon GDP in national currency.

\section{CHART 2}

\begin{tabular}{|lcccccc|}
\hline \multicolumn{7}{|c|}{ Singapore: Macroeconomic Indicators } \\
Real GDP Growth (\%) & $\underline{1995}$ & $\frac{1996}{7.2}$ & $\underline{1997}$ & $\underline{1998}$ & $\underline{1999}$ & $\underline{2000}$ \\
Inflation Rate* (\%) & 1.7 & 1.4 & 2.0 & -0.3 & 0.0 & 1.3 \\
\hline
\end{tabular}

Source: IMF, International Financial Statistics Yearbook

* Avg. Consumer Prices 